\title{
The demise of the Early Eocene Greenhouse - Decoupled deep and surface water cooling in the eastern North Atlantic
}

\author{
André Bornemann ${ }^{\mathrm{a}, *}$, Simon D'haenens ${ }^{\mathrm{b}}$, Richard D. Norris ${ }^{\mathrm{c}}$, Robert P. \\ Speijer $^{\mathrm{d}}$ \\ ${ }^{a}$ Bundesanstalt für Geowissenschaften und Rohstoffe, Stilleweg 2, 30655 Hannover, \\ Germany \\ ${ }^{b}$ Department of Geology and Geophysics, Yale University, 210 Whitney Avenue, New \\ Haven, CT 06511, USA \\ ${ }^{c}$ Scripps Institution of Oceanography, University of California - San Diego, 300C Ritter \\ Hall, La Jolla, CA 92093-0244, USA \\ ${ }^{d}$ Department of Earth and Environmental Sciences, KU Leuven, Celestijnenlaan 200E, \\ 3001 Heverlee, Belgium
}

\begin{abstract}
Early Paleogene greenhouse climate culminated during the early Eocene Climatic Optimum (EECO, 50 to $53 \mathrm{Ma}$ ). This episode of global warmth is subsequently followed by an almost 20 million year-long cooling trend leading to the Eocene-Oligocene glaciation of Antarctica. Here we present the first detailed planktic and benthic foraminiferal isotope single site record $\left(\delta^{13} \mathrm{C}, \delta^{18} \mathrm{O}\right)$ of late Paleocene to middle Eocene age from the North Atlantic (Deep Sea Drilling Project Site 401, Bay of Biscay). Good core recovery in combination with well preserved foraminifera makes this site suitable for correlations and comparison with previously published long-term records from the Pacific Ocean (e.g., Allison Guyot, Shatsky Rise), the Southern Ocean (Maud Rise) and the equatorial Atlantic (Demerara Rise). Whereas our North Atlantic benthic foraminiferal $\delta^{18} \mathrm{O}$ and $\delta^{13} \mathrm{C}$ data agree with the global trend showing the long-term shift toward heavier $\delta^{18} \mathrm{O}$ values, we only observe minor surface water $\delta^{18} \mathrm{O}$ changes during the middle Eocene (if at all) in planktic foraminiferal data. Apparently, the surface North Atlantic did not cool substantially during the middle Eocene. Thus, the North Atlantic appears to have had a different surface ocean cooling history during the middle Eocene than the southern hemisphere, whereas cooler deep-water masses were comparatively well mixed. Our results are in agreement
\end{abstract}

\footnotetext{
* Corresponding author

Email address: andre.bornemann@bgr.de (André Bornemann)
}

Preprint submitted to Global and Planetary Change

23. August 2016 
with previously published findings from Tanzania, which also support the idea of a muted post-EECO surface-water cooling outside the southern high-latitudes.

Keywords: Paleocene, Eocene, North Atlantic, paleoclimate, foraminifera, stable isotopes

2010 MSC: 00-01, 99-00

\section{Introduction}

The Paleogene represents a prominent long-term climate transition in Earth history with a late Paleocene to middle Eocene interval that is characterized by a long-term global warmth $[93,89,52]$. The existence of a late Paleocene-

5 early Eocene greenhouse is supported by numerous paleontological, isotopic and sedimentological findings suggesting temperatures in subpolar regions and ocean bottom waters that were up to $10^{\circ} \mathrm{C}$ higher than today [e.g. 88, 2, 93, 5, 89, 78, 77, 67, 25]. Polar ice-sheets were either small or did not exist [23, 46, 71, 79]. The Paleocene-Eocene warmth culminated in the Early Eocene Climatic

10 Optimum [EECO; 50-53 Ma, 81], and was subsequently followed by a long-term cooling, which finally led to the Oligocene icehouse [e.g 44, 45, 93]. Most authors have invoked high atmospheric $\mathrm{pCO}_{2}$ levels to explain the greenhouse climate mode, while the post-EECO cooling has often been attributed to a decline of atmospheric $\mathrm{pCO}_{2}$ concentrations $[61,14,56,91]$.

15 Our current view of temperature trends and prevailing paleoceanographic conditions during the early Paleogene relies on multi-site composite benthic foraminiferal $\delta^{18} \mathrm{O}$ records $[93,89,91,12]$ compiled from multiple drill sites in different ocean basins. These records provide an average signal of the deep ocean. Presently, most single site planktic foraminifera stable isotope data are

20 of low resolution or based on poorly preserved foraminiferal calcite. High quality paleotemperature data are particularly lacking for the Eocene North Atlantic. Other than the tropical Demerara Rise records (ODP Sites 1258 and 1260) of [67], no long-term single site benthic foraminiferal record with an adequate temporal resolution for the early to middle Eocene has been published from this 25 region.

The reasons for these limitations are due to the lack of deep-sea sites which provide both: (1) good core recovery of sediments spanning the study interval; existing North Atlantic records are typically punctuated by frequent occurrences of chert layers, condensation and major hiatuses covering up to 2 million years 
30 particularly across the early-middle Eocene transition [e.g. 1, 53, 50], (2) suitable microfossil preservation that allows for reliable geochemical proxy data, particularly for planktic foraminifera.

Here we present new long-term stable isotope records $\left(\delta^{13} \mathrm{C}, \delta^{18} \mathrm{O}\right)$ of foraminiferal calcite from the North Atlantic (Deep-Sea Drilling Project (DSDP)

35 Site 401, Bay of Biscay) covering the latest Paleocene to middle Eocene interval ( 57-40 Ma). Key features of this time interval include a number of transient warming events (of 100-200 kyr duration) such as the well known PaleoceneEocene Thermal Maximum [PETM, 56 Ma; e.g. 31, 70, 43] and Eocene Thermal Maximum 2 [ETM2, 54.1 Ma; e.g. 40, 73, 72, 15], but also numerous similar,

40 less pronounced events of early Eocene age [13, 66, 32]. On a multi-million year timescale, secular variations in the carbon cycle are reflected in the $\delta^{13} \mathrm{C}$ of biogenic carbonates showing the long-term $\delta^{13} \mathrm{C}$ decline across the PaleoceneEocene transition. This decrease resulted in a Paleogene $\delta^{13} \mathrm{C}$ minimum period between 52 and 54 Ma which marks the onset of the long-term warmth of the 45 EECO. While previous recent studies from the Paleocene-Eocene interval of Site 401 are exclusively focused on the PETM and ETM2 [10, 16, 15], this paper discusses the long-term evolution of the North Atlantic during the latest Paleocene to middle Eocene across the EECO interval of peak warmth (EECO).

The new long-term stable isotope records from DSDP Site 401 comprise not only benthic foraminifera representing bottom water conditions. We also present stable isotope data for planktic foraminifera as a measure of subsurfacethermocline and surface mixed-layer conditions. Until now no detailed information on the upper ocean structure and the surface water temperature trends are available for the EECO and middle Eocene from the Northeastern Atlantic, 55 thus, our records allow us to unravel the response of the entire water column and to compare our North Atlantic records of this globally warm period to previously published ones from the Pacific [11, 17, 18, 90, 85], the equatorial and South Atlantic [67, 4, 39] and the Southern Ocean [30, 74] for different water masses. We further examine inter-ocean basin $\delta^{13} \mathrm{C}$ bottom water gradients as

60 a proxy of deep-water circulation patterns and discrepancies in surface water response to the long-term middle Eocene bottom water cooling trend [59, 28]. 


\section{Material and methods}

\subsection{Location and lithology}

DSDP Site $401\left(47^{\circ} 25.65^{\prime} \mathrm{N}, 8^{\circ} 48.62^{\prime} \mathrm{W}\right)$ is located on the Meriadzek Terrace

65 on the northern margin of the Bay of Biscay, eastern North Atlantic [47](Fig. 1). During the PETM (56 Ma) this site was located at $\sim 42^{\circ} 32^{\prime} \mathrm{N}$ and $10^{\circ} 25^{\prime} \mathrm{W}$ [43], making it (along with DSDP Site 550) one of the most northern scientific drill sites to provide pelagic carbonates of Paleogene age. Site 401 was drilled at a water depth of $2495 \mathrm{~m}$ [47], the paleo-water depth for the early Eocene is 70 estimated at 1.8 to $2 \mathrm{~km}$ based on benthic foraminifera [16].

Core recovery of the $\sim 95$-m-thick sequence is nearly complete for the latest Paleocene to early middle Eocene (c. 90\%; cores 7-14), whereas the two uppermost cores 5 and 6 have only been partly recovered (Fig. 2). We took samples at a resolution of four samples per core section from cores 15 to 5 (depth interval

$75 \sim 212-110 \mathrm{mbsf}$ ), whereas core 14 (PETM) and core 13 (ETM2) were sampled at a much higher resolution $[16,15,10]$.

The uppermost Paleocene to middle Eocene sedimentary succession consists of yellowish-brown to orange-brown nannofossil marls and marly chalks (Fig. 2). Sediment color cyclicity is apparent for the studied Eocene sequence reflecting

so changes in $\mathrm{CaCO}_{3}$ and clay content. The PETM and ETM2 beds are darker, with less carbonate and a higher clay content (Fig. 2) than the rest of the section $[16,10]$.

\subsection{Stratigraphy and age models}

The stratigraphic framework for DSDP Site 401 is primarily based on cal-

85 careous nannofossil biostratigraphy following established zonation schemes of [41] and [55]. The zonal boundaries identified in this paper are largely in agreement with those of [48], but due to a higher sampling resolution the position of some boundaries have been slightly adjusted. To a lesser extent planktic foraminiferal biozones have been integrated into our age-depth model (Fig. 2).

90 Absolute ages for biozonal boundaries, magnetostratigraphic datums [1], and paleoclimate events (PETM, ETM2) are based on the Geological Time Scale 2012 [GTS2012, 81]. The resulting age model (Fig. 2) allows us to separate the long-term record into three phases: (1) the Paleocene to early Eocene (c. 57 to $51 \mathrm{Ma}$ ) which is characterized, by an average pelagic sedimentation rate (SR)

95 of about $0.5 \mathrm{~cm} / \mathrm{kyr},(2)$ a condensed early/middle Eocene boundary interval (c. 51 to $45 \mathrm{Ma}$ ) representing possibly one or more hiatuses (average SR 0.06 
$\mathrm{cm} / \mathrm{kyr}$ ), and (3) lower middle Eocene (45 to $41 \mathrm{Ma}$ ) showing again a higher $\mathrm{SR}$ $(1.3 \mathrm{~cm} / \mathrm{kyr})$ (Fig. 2).

In order to compare DSDP Site 401 with other Eocene records we adopted

100 previously published bio-, event- and magnetostratigraphy of sites around the world and re-calibrated those according to GTS2012. For the central Pacific ODP Site 1209 the age model is based on [86, 87, 85] and for ODP Site 865 on [11], [34] and [75]. The age model of ODP Site 1262 (South Atlantic) follows [87, solution 2], and that of ODP Site 690 at Maud Rise calcareous nannofossil biostratigraphy by [63]. For Demerara Rise in the western equatorial Atlantic (ODP Sites 1258 and 1260) the age model of [67] is used.

\subsection{Methods}

Samples were analyzed with respect to their $\mathrm{CaCO}_{3}$ content employing the carbonate bomb technique [49]. For TOC approximately $100 \mathrm{mg}$ of sediment were decalcified with $10 \% \mathrm{HCl}$ and dried for about 12 hours at $90^{\circ} \mathrm{C}$. TOC has been analyzed by using an ELTRA Metaly CS 100/100. The precision for replicate analyses is $2 \mathrm{wt} \%$ for $\mathrm{CaCO}_{3}$ and $0.05 \mathrm{wt} \%$ for TOC. Most $\mathrm{CaCO}_{3}$ values and isotope measurements from the PETM and ETM2 intervals have previously been published $[16,15,10]$.

115 Foraminifera samples were dried at $\sim 50^{\circ} \mathrm{C}$, weighed, soaked in tap water for 24 hours, gently washed under running water through a $63 \mu \mathrm{m}$ sieve, dried and weighed again. For stable isotope analyses $\left(\delta^{13} \mathrm{C}, \delta^{18} \mathrm{O}\right)$ of foraminifera various taxa have been analyzed. Bottom water conditions are reflected by benthic foraminiferal calcite. Here we used epibenthic Nuttallides truempyi for isotope analyses, however, due to the scarcity of $N$. truempyi in some intervals of the Eocene we analyzed various Cibicidoides species. All values of N. truempyi have been corrected towards Cibicidoides following [29]. Subsurface waters are best reflected by Subbotina species, and surface water conditions by the photosymbiont-bearing Acarinina, Morozovella and Morozovelloides. Planktic 125 foraminifera were picked on the species-level from the 250-400 $\mu \mathrm{m}$ size fraction. However, within some intervals of the Eocene well-preserved specimens were rare, in these cases we had to pick some samples at genus-level.

For each measurement between 3 and 10 specimens were analyzed using a Kiel III on-line carbonate preparation line connected to a ThermoFinnigan 252 130 mass spectrometer at the Erlangen University, Germany. Foraminiferal tests were reacted with $100 \%$ phosphoric acid [density $>1.983$ ] at $75^{\circ} \mathrm{C}$. All values are reported in \%o relative to Vienna Pee Dee Belemnite (V-PDB) by assigning 
a $\delta^{13} \mathrm{C}$ value of $+1.95 \%$ and a $\delta^{18} \mathrm{O}$ value of $-2.2 \%$ to NBS19. Reproducibility was checked by replicate analyses of laboratory standards (IAEA-CO1) and is

135 better than $0.02(1 \mathrm{~s})$ for both $\delta^{13} \mathrm{C}$ and $\delta^{18} \mathrm{O}$. In order to estimate absolute temperatures we used the [69] equation for benthic foraminifera and [21] for planktic foraminifera. An estimated sea-water $\delta^{18} \mathrm{O}_{s w}$ of $-0.4 \%$ SMOW has been used for the surface waters at Site 401 based on a numerical model of [76] that assumes ice-free conditions for the Eocene. This value is well in line with

140 an independent model of [26]. For the comparison sites we also applied values given by [76] (see also the corresponding figure captions). For thermocline and deep-waters at all sites we used a sea-water $\delta^{18} \mathrm{O}_{s w}$ of $-0.96 \%$ according to [93] assuming ice-free conditions.

\section{Results and discussion}

\subsection{Preservation}

Calcite preservation is crucial for interpreting foraminiferal stable isotope data in paleoceanographic research. Diagenetic alteration of foraminiferal calcite can have a significant impact on the $\delta^{13} \mathrm{C}$ and $\delta^{18} \mathrm{O}$ signature, specifically if recrystallization and precipitation of diagenetic calcite took place [e.g. 58, 19]. While $\delta^{13} \mathrm{C}$ of recrystallized planktic foraminifera from deep-sea cores usually shows similar values as unaltered calcite, $\delta^{18} \mathrm{O}$ tends to increase due to the bottom-water signal recorded by precipitated secondary calcite during early diagenesis. Previous studies suggest that absolute $\delta^{18} \mathrm{O}$ values are changed through recrystallization, but general trends of $\delta^{18} \mathrm{O}$ changes remain largely preserved

[e.g. 58]. At Site 401 we visually examined the preservation of foraminifera using a binocular stereo microscope during the picking process, but also examined some specimens using scanning electron microscopy (Fig. 3). The PETM and ETM2 intervals are largely characterized by well preserved foraminiferal tests with semi-translucent to opaque skeletons [10, 15]. For the Paleocene and the remaining Eocene the preservation becomes somewhat poorer with opaque shells and clogging of some pores, but otherwise well preserved shell microstructure, particularly close to the condensed interval at the early-middle Eocene transition, overall preservation is still considered good. Foraminiferal tests analyzed were unfilled, and displayed primary features like pores, keel structures and openings (Fig. 3), in the worst case signs of incipient recrystallization and precipitation of secondary calcite were observed. 


\subsection{Stable isotope results from DSDP Site 401}

Depth habitats of the studied planktic foraminifera taxa as inferred from the isotope data are well in line with interpretations in the current literature [see 60, for an overview]. Morozovella/Morozovelloides, Acarinina and Globoturborotalita inhabited a surface water niche and had a photosymbiotic life style as suggested by heavy $\delta^{13} \mathrm{C}$ and light $\delta^{18} \mathrm{O}$ values (Fig. 4). A subsurface habitat, presumably at thermocline depth for Subbotina and Hantkenina is indicated by intermediate values between the surface dwelling and epibenthic foramini-

175 fera (Cibicidoides, Nuttallides truempyi), which indicate the lowest temperatures by displaying the heaviest $\delta^{18} \mathrm{O}$ and the lightest $\delta^{13} \mathrm{C}$ values. Globigerinatheka shows values that are between the surface and subsurface dwellers. The lighter $\delta^{13} \mathrm{C}$ of Globigerinatheka compared to other taxa argues for a nonphotosymbiotic life style, and the light $\delta^{18} \mathrm{O}$ reflects a depth habitat that was 180 only slightly deeper than for Morozovella/Morozovelloides and Acarinina possibly at the base of the surface mixed-layer. In previous studies Globigerinatheka has been interpreted to inhabit a mixed-layer habitat with a tendency to sink to deeper depths for gametogenesis $[9,62,58,64,68]$, however, there is also evidence for existence of photosymbionts in other studies [62, 58]. Since the analyzed Globigerinatheka specimens showed a slight encrustation we propose a deeper habitat during gametogenesis and precipitation of a gametogenic calcite crust.

\subsubsection{Long-term trends}

Since our records reveal the typical relative offsets for both $\delta^{13} \mathrm{C}$ and $\delta^{18} \mathrm{O}$ tracing the different depth habitats, relative changes in these gradients can be used to draw conclusions concerning the stability of surface water stratification as well as relative changes in temperature and productivity of the different water masses through time.

For $\delta^{13} \mathrm{C}$ the values of subsurface dwellers and benthic foraminifera are very close together with an average offset of $<1 \%$, which is within the range of modern oceanic $\delta^{13} \mathrm{C}_{D I C}$ gradients between thermocline and bottom waters [e.g., $35]$. Values for the surface dwellers are $\sim 2 \%$ heavier than for the subsurface ones (Figs. 4 and 5). In contrast, $\delta^{18} \mathrm{O}$ values of subsurface dwelling foraminifera are more similar to the surface dwellers. This difference in the behavior of the subsurface Subbotina can at least partly be attributed to the strong photosymbiotic effect in the surface-dwelling morozovellids which exaggerates the $\delta^{13} \mathrm{C}$ gradient between the two planktic groups. The $\delta^{18} \mathrm{O}$ gradient between the depth habitats 
becomes weaker and almost disappears during the early Eocene (upper NP10 to NP14 nannofossil biozones, 186-170 mbsf) suggesting enhanced vertical mixing 205 of the water masses during the EECO. The $\delta^{13} \mathrm{C}$ gradient diminishes only at the NP10/NP11 boundary, and remains rather constant throughout the remaining Eocene. However, considering only the non-photosymbiotic subbotinids the $\delta^{13} \mathrm{C}$ gradient is small for the same long interval as for $\delta^{18} \mathrm{O}$. The photosymbiont-effect on $\delta^{13} \mathrm{C}$ of surface dwelling foraminifera is probably masking the long-term at210 tenuation of the benthic-planktic gradient (Fig. 4). Higher temperatures during the EECO are visible in all studied foraminifera groups, and suggests that the entire ocean warmed up during the EECO. In contrast there is a well developed post-EECO cooling trend in benthic foraminiferal $\delta^{18} \mathrm{O}$.

For $\delta^{18} \mathrm{O}$ the gradient between benthic and planktic foraminifera becomes more pronounced in the middle Eocene with a relatively constant difference of $2 \%$ which equals $\sim 8^{\circ} \mathrm{C}$ temperature difference; by contrast it is only $<1 \%$ $\left(\sim 4^{\circ} \mathrm{C}\right)$ during the NP11-NP14 interval. This contrast reflects the long-term bottom water cooling seen in benthic foraminifera, while the isotopic composition of planktic foraminifera remains nearly unchanged.

220 Long-term changes in $\delta^{13} \mathrm{C}$ follow the well-known secular trends of the global carbon cycle. [33] ascribe the long-secular changes during the late Paleoceneearly Eocene to changes in the organic carbon burial, specifically Arctic coal, whereas a decrease in net organic carbon burial may represent enhanced oxidation of previously deposited organic matter as peat or gas hydrates.

225 3.2.2. Short-term changes

The long-term record is interrupted by a number of the transient hyperthermal events such as the PETM ( 202.5 mbsf) and ETM2 ( 191 mbsf) as indicated by sharp drops in $\delta^{13} \mathrm{C}$ and $\delta^{18} \mathrm{O}[10,15]$. A third negative peak at $\sim 183.5$ mbsf of $\sim 1 \%$ in $\delta^{13} \mathrm{C}$ has been observed close to a stratigraphic position 230 where ETM3 usually occurs, however, the broad peak seems to cover a longer interval than expected for ETM3, raising the question of whether this $\delta^{13} \mathrm{C}$ peak is indeed ETM3. The modest temporal resolution of our record restricts our ability to confidently detect the series of minor hyperthermal-like events during the $\sim 5$ myr interval following the EECO as observed at other deep-sea 235 sites [e.g. 13, 66, 92]. 


\subsection{Supra-regional long-term comparison}

A comparison between Site 401 with previously published records reveals many similarities, but also sheds new light on the early and middle Eocene climate evolution in the North Atlantic region (Figs. 6 and 7). We consider the comparison of benthic foraminifera records to be broadly reliable, since seafloor diagenesis at some of our comparison sites should still produce seafloor isotopic ratios in benthic foraminiferal calcite [20, 82]. In recrystallized material, planktic foraminifera isotope data are likely to be reset toward seafloor isotopic ratios and therefore track conditions in the deep ocean rather than the surface waters 245 [e.g., 58].

Specifically the reliability of planktic foraminifera isotope values from the Pacific Sites 865 and 1209 have been questioned due to the strong degree of recrystallization $[59,57,34]$. Whereas a global bottom water cooling based on benthic foraminiferal $\delta^{18} \mathrm{O}$ is generally accepted, doubt has been shed on an accompanied surface water cooling at low-latitudes based on results from the $\mathrm{TEX}_{86}$ SST proxy and $\delta^{18} \mathrm{O}$ of excellently preserved planktic foraminifera from Tanzania [59, a more detailed discussion can be found in section 3.3.2]. The process of recrystallization is expected to shift planktic foraminiferal calcite toward the composition of benthic foraminifera, accounting for the parallel trends in 255 both groups through the middle Eocene at both Pacific sites. The latter might also apply to some extent to the Demerara Rise samples that also display signs of recrystallization [4].

Benthic foraminiferal $\delta^{13} \mathrm{C}$ and $\delta^{18} \mathrm{O}$ of Site 401 are both very similar to the global compilations of [12] and [89, 91, Fig. 6A and D]. Subsurface and surface dwelling foraminiferal $\delta^{13} \mathrm{C}$ values from the Pacific sites show usually somewhat heavier than those of Site 401 before $46 \mathrm{Ma}$ [e.g. 11, 17]. During the earliest Eocene the $\delta^{13} \mathrm{C}$ gradient between between 401 and the Pacific sites is very pronounced (up to $\sim 2 \%$ ) and larger in surface planktic foraminifera than in subsurface taxa. This might be explained by potentially warmer and more oligotrophic conditions in the Pacific that possibly forced enhanced photosymbiotic activity [51]. Moreover, higher clay and terrestrial carbon input rates associated with enhanced freshwater runoff into the eastern North Atlantic as also reflected by the generally darker sediment color (Fig. 2) during most of the early Eocene might also have caused a lower $\delta^{13} \mathrm{C}_{\text {DIC }}$. After 46 Ma relatively uniform $\delta^{13} \mathrm{C}$ values for all habitats are observed at all sites (Fig. 6A and D).

As shown in Fig. $6 \mathrm{E}, \delta^{18} \mathrm{O}$ of the subsurface dwellers display the expected order with the heaviest values for Site 690 followed by the Pacific and Atlantic 
values. For the surface dwellers the lightest $\delta^{18} \mathrm{O}$ data (Figs. $6 \mathrm{~F}$ and 7 ) reflecting the highest temperatures are recorded for the Eocene of Demerara Rise (equatorial western Atlantic) followed by the Pacific and North Atlantic values that both suggest broadly similar SSTs (Fig. 7). Coolest conditions are observed in the $\delta^{18} \mathrm{O}$ of Maud Rise (Southern Ocean).

It is striking that the long-term cooling is not apparent or only weakly developed in planktic foraminiferal $\delta^{18} \mathrm{O}$ at Site 401 (Figs. 6 and 7), whereas all

280 other Eocene records show a temperature decline by $\sim 6^{\circ} \mathrm{C}$ between the EECO (50-53 Ma) and the top of our record at $40 \mathrm{Ma}$. The post-EECO cooling pattern is most pronounced at Maud Rise and Demerara Rise.

The largest planktic-benthic temperature gradient has been recognized for the equatorial Atlantic with $15^{\circ} \mathrm{C}$, and about $8^{\circ} \mathrm{C}$ at Sites 401,865 and 1209

285 (Fig. 7). However, the depth-gradient became weaker by $\sim 4^{\circ} \mathrm{C}$ at both Pacific sites after $51 \mathrm{Ma}$, which is very small for such a deep setting in the low latitudes and, thus, points also to severe diagenetic alteration of planktic foraminiferal $\delta^{18} \mathrm{O}$. At Site 690 the temperature gradient is very muted arguing for enhanced vertical mixing at this site and potential deep-water formation (Fig. 7) as

290 previously suggested by [75] based on neodymium isotopes. The disappearance of the surface to bottom-water gradient may be somewhat overstated due to a potential diagenetic alteration and uncertainties in the assumed $\delta^{18} \mathrm{O}_{S W}$ composition, however, the chosen value of $-1.2 \%$ is suggested by two independent models $[26,76]$ and minor changes still suggest the presence of a small

295 surface to bottom-water gradient. Moreover, enhanced vertical mixing in the Southern Ocean is supported by numerical modeling. While mean annual stratification increases almost everywhere during warmer climates [65, 8], a weaker stratification associated with enhanced vertical convection has been observed in numerical simulations at the southern high latitudes due to surface water

300 cooling during Austral winters [8] as probably reflected by the small thermal benthic-planktic gradient at Site 690 .

In the following we focus on two key features of the early to middle Eocene interval, where Site 401 provides new clues to North Atlantic paleoceanography.

\subsubsection{Early-middle Eocene transition}

The early-middle Eocene transition coincides with the start of the long-term deep-water cooling following the EECO (Figs. 4-7). In deep-marine sediment sequences of the North Atlantic the early-middle Eocene boundary is usually represented by an hiatus of $\sim 1$ to 2 myr duration $[1,53]$ and has, thus, rarely 
been recovered during ocean drilling. This stratigraphic level corresponds in age

lithological transition from chert to biosilica-rich ooze [80].

At DSDP Site 401 a drop in average sedimentation rates from 0.5 to $<0.1$ $\mathrm{cm} / \mathrm{kyr}$ indicate the existence of a major hiatus covering most of nannofossil biozone NP14, which is well in line with findings from other places in the North low sedimentation rates might span up to four million years resulting in low data resolution for this interval (Figs. 5 and 6). Further, the interval is characterized by a change in sediment color from reddish-brown below to pale brown above NP14 (Fig. 2). $\mathrm{CaCO}_{3}$ shows high fluctuations during the Paleocene and early 320 Eocene with minimal values (26 wt\%) right below and very high values (80 wt \%) directly above this potential hiatus, but then remains remarkably stable with cyclically changing values between 40 and $70 \mathrm{wt} \%$ in the middle Eocene (Fig. 4). Sedimentation rate increases to $>1.2 \mathrm{~cm} / \mathrm{kyr}$ as also indicated by the expanded thickness of calcareous nannofossil biozones NP15 and NP16.

325 Recently drilled sites off Newfoundland [22] consistently record a drop in $\mathrm{CaCO}_{3}$ by about $40 \mathrm{wt} \%$ at the $\mathrm{C} 21 \mathrm{r} / \mathrm{C} 21 \mathrm{n}$ transition which lies within nannofossil biozone NP14. This sharp decline of $\mathrm{CaCO}_{3}$ goes along with a general increase in MAR at these sites, which might indicate intensification of the bottom water current carrying high loads of fine-grained siliciclastics and biosilica to form the first sedimentary drifts in the North Atlantic. Considering the substantial increase in $\mathrm{CaCO}_{3}$ at Site 401, and assuming a largely uniform CCD depth in the North Atlantic basin we propose that the major decrease in $\mathrm{CaCO}_{3}$ off Newfoundland is at least partly due to dilution by clays and biosilica.

At almost the same time intensification of deep-water currents across this 335 boundary is proposed by the contemporaneous onset of sediment drift deposits within a restricted sedimentary basin at the Greenland-Scotland Ridge, a key gateway for Arctic Ocean outflow into the North Atlantic [24]. Also at Blake Nose in the western North Atlantic, winnowed foraminiferal sands have been deposited across the early-middle Eocene boundary disconformity [48-49 Ma

340 54] contemporary to the increase in sedimentation rates at Site 401 as reflected by the expanded NP15 and NP16 interval. It seems that the entire North Atlantic has experienced a change in the sedimentation regime with an increase in deposition of fine grained material resulting in the first drift complexes or at least in general higher thicknesses of the NP15-NP16 interval. 
threshold transition in Earth's climate evolution, since it coincides not only with a widespread hiatus, but also with (i) the onset of the post-EECO global deepwater cooling trend [91], and (ii) major changes in deep-sea circulation as evident through the development of a strong global interbasinal $\delta^{13} \mathrm{C}$ gradient [67]. The latter has been interpreted to reflect either a switch to a single site of deep water formation and/or a substantial increase in biological export production and remineralization [e.g. 42]. In contrast to [67], the increase of the interbasinal $\delta^{13} \mathrm{C}$ gradient is not obvious in our compilation (Fig. 6A) due to lack of the multi-site Indian Ocean data used by [67] and [24].

At Site 401 we observed an increase in the surface to bottom-water gradient that coincides with major changes in deep-sea circulation as indicated by the increase in sedimentation rates and the onset of the post-EECO deep-water cooling trend (Fig. 4). Further a crossover in planktic $\delta^{18} \mathrm{O}$ between Pacific data and Site 401 is observed during this interval (Fig. 6). The Pacific $\delta^{18} \mathrm{O}$ values became increasingly heavier indicating surface ocean cooling or more likely increased seafloor diagenesis, whereas the North Atlantic data remain relatively stable.

\subsubsection{Post-EECO surface ocean - cooling or non-cooling?}

The long-term post-EECO cooling is a prominent feature of most open365 oceanic benthic foraminiferal $\delta^{18} \mathrm{O}$ records $[12,93,89,91]$. This temperature decline is not only recorded in benthic foraminiferal $\delta^{18} \mathrm{O}$, but also in other proxy data such as benthic foraminiferal $\mathrm{Mg} / \mathrm{Ca}[38,17,25]$, and for the surface ocean by $\operatorname{TEX}_{86}[7,6,25,28]$, specifically in the Southern Ocean, and from planktic foraminiferal $\delta^{18} \mathrm{O}$ in the central Pacific $[11,17]$ and Demerara Rise

370 [4, Fig. 7]. In order to explain this long-term cooling trend two mechanisms are usually discussed: (i) tectonic changes in the southern hemisphere, specifically the opening of the Tasmanian gateway or the Drake Passage [e.g. 37, 36] and (ii) a decline in atmospheric $\mathrm{pCO}_{2}$ and/or other greenhouse gases [56, 91]. [6] made a strong case for the opening of Tasmanian gateway about 49 Ma that initia375 ted the westward flow of the Antarctic counter current based on changes in the biogeographic pattern of dinoflagellate cysts. At the same time $\mathrm{TEX}_{86}$ derived SSTs start to decline by 2 to $4^{\circ} \mathrm{C}$. In contrast, [28] attribute only $10 \%$ of the observed middle Eocene cooling to an ocean gateway-induced reorganization of ocean currents. Based on numerical modeling they postulate a decline in green-

380 house gas concentrations specifically $\mathrm{pCO}_{2}$. However, the same authors point out that the evolution of $\mathrm{pCO}_{2}$ during the Eocene is still poorly constrained. [6], 
in turn, argue that the difference in SSTs between rather constant low-latitude and mid-latitude North Atlantic data is difficult to explain by atmospheric $\mathrm{CO}_{2}$ forcing alone. This view is also supported by a Cenozoic $\mathrm{pCO}_{2}$ compilation of 385 [52] which displays no substantial $\mathrm{pCO}_{2}$ decline from the EECO to the late Eocene. All this suggests that $\mathrm{pCO}_{2}$ is not the main driver behind the middle Eocene cooling. The lack of large permanent Antarctic ice sheets and, thus, of enhanced southern hemisphere albedo requires other mechanisms to explain the global SST patterns, such as the effects of gateways in combination with a minor to moderate decline in atmospheric $\mathrm{pCO}_{2}[91]$.

Whereas a global bottom water cooling is generally accepted, doubt has been shed on an accompanied surface water cooling at low-latitudes based on results from the $\mathrm{TEX}_{86}$ SST proxy and $\delta^{18} \mathrm{O}$ of excellently preserved planktic foraminifera from Tanzania [59, 57]. These authors propose that the planktic foraminifera-based temperature signal has been substantially altered by diagenetic recrystallization at both Pacific sites, which is also supported the reevaluation of the data in this study, e.g., through the aforementioned abnormally low benthic-planktic gradient and our temperature comparison between sites (Fig. 6). Since the paleolatitude of ODP Site 865 (Allison Guyot) was $\sim 7^{\circ} \mathrm{N}$ in 400 the early Eocene, and $\sim 23^{\circ} \mathrm{N}$ at Shatsky Rise Site 1209 [at $56 \mathrm{Ma}, 43$ ], it is reasonable to assume that SSTs from Site 865 should have been constantly higher than at Site 1209, and those of both Pacific sites higher than at Site $401\left(42^{\circ} \mathrm{N}\right)$. This expected pattern has been indeed observed between 56-51 Ma with SST of $\sim 25^{\circ} \mathrm{C}$ for Site $865, \sim 22^{\circ} \mathrm{C}$ for Site 1209 and $\sim 20^{\circ} \mathrm{C}$ for Site 401 , however, 405 the SST estimates all converge at the early-middle Eocene transition and the younger part of the record (Fig. 7). The Demerara Rise record is distinctly warmer than the Pacific throughout the whole record. The warm Atlantic waters might reflect a warm pool there compared location of 865 and 1209 in cooler mid Pacific waters. However, the $\sim 30^{\circ} \mathrm{C}$ EECO record from Demerara Rise seems 410 unusually warmer than the warmest Pacific SSTs $\left(\sim 25^{\circ} \mathrm{C}\right)$ suggesting that Pacific value may be strongly under-estimated due to diagenetic overprinting in the planktic foraminifera records.

[28] reevaluated existing $\mathrm{TEX}_{86}$ records considering a new interpretation and calibration of existing data. Similar to [7] they observed an up to $6^{\circ} \mathrm{C}$ cooling ${ }_{415}$ in the high latitudes, whereas the low-latitude cooling does not exceed $2^{\circ} \mathrm{C}$ over our study interval [LOESS regression data, 28], or is almost non existent as in the Tanzania record [59]. Unfortunately the mid-latitude North Atlantic is again underrepresented in terms of $\mathrm{TEX}_{86}$ data. Only a low-resolution record 
of New Jersey Shelf sediments [South Dover Bridge, 28] represents a similar 420 paleolatitude as Site 401. However, the interval of interest is covered by only three data points which tentatively suggest a $2^{\circ} \mathrm{C}$ cooling. From the high latitude Site 913 east of Greenland no early Eocene and early middle Eocene data are available. Hence, neither the Greenland site nor New Jersey allow for a detailed interpretation of SSTs in the North Atlantic for the study interval. After re-

${ }_{425}$ evaluating existing literature data and considering our planktic foraminiferal $\delta^{18} \mathrm{O}$ results we suggest an asymmetric surface water cooling between the midto high-latitudes in the southern hemisphere where surface water cooling is well documented, and the low latitudes and northern hemisphere (Fig. 6), where the amount of temperature decline is either limited or somewhat questionable.

${ }_{430}$ However, available data sets for the low latitudes and the northern hemisphere are still very limited, and more reliable SST data are needed to confirm the proposed spatial cooling pattern. As one possible explanation for the diminished surface water cooling in the eastern North Atlantic we propose the existence of an Eocene (proto-)Gulf stream [26] that brings continuously warm surface

435 waters to the Bay the Biscay and compensates any existing atmospheric cooling in this region.

Southern ocean surface waters are known to be the primary source for intermediate and deep waters in the ocean overturning system during the Eocene $[7,27]$. This is supported specifically by neodymium isotope data [e.g., 75]. Fur-

${ }_{440}$ ther pollen-based reconstructions suggest that intermediate water production primarily took place during the winter season when cold, dense water convected downward in the Southern Ocean [7]. Another piece of evidence for deep-water formation in this area comes from the almost absent benthic-planktic temperature gradient at Site 690 (Fig. 7). In addition, intermediate water carbon isoto-

445 pe gradients between ocean basins also suggest increased formation of Southern Ocean intermediate waters in the Eocene [24].

[67] argue that a strong correlation between interbasin isotope gradients points to a link between water mass aging and background ocean temperatures during Eocene warmth. A diminished gradient between ocean basins may either 450 suggest multiple deep water sources during temperature maxima or, in the case of $\delta^{13} \mathrm{C}$ a reduction in biological pump efficiency. These authors suggest that northern hemisphere deep water formation must have been minimal due to the low $\delta^{13} \mathrm{C}$ signatures of both Pacific and Atlantic oceans. Moreover, the temperature gradient between low latitudes and southern high latitudes based on $\mathrm{TEX}_{86}$ 455 data becomes stronger from the onset of post-EECO cooling onward, suppor- 
ting also a polar trigger for the long-term cooling [28]. An additional deep-water source has been proposed by [24] from the North Atlantic at the early-middle Eocene boundary, which they interpreted as the initiation of North Atlantic Deep Water formation. However, [6] assumed that this water mass would have 460 flooded a depth below the CCD and is, thus, not reflected in any benthic isotope data analyzed so far from the North Atlantic. These lines of evidence in combination with enhanced surface water cooling in the Austral realm suggest that the early and middle Eocene $\delta^{18} \mathrm{O}$ of benthic foraminifera recorded at Site 401 and elsewhere in the open oceans is controlled by intermediate and/or bottom waters that formed in the mid- to high latitudes of the southern hemisphere.

\section{Conclusions}

The new multispecies benthic and planktic foraminiferal $\delta^{13} \mathrm{C}$ and $\delta^{18} \mathrm{O}$ records of DSDP Site 401 provide a detailed paleoceanographic single site record of the North Atlantic for the uppermost Paleocene to middle Eocene interval.

The following key results have been revealed:

1. The early Eocene data display well pronounced records of two transient warming events (PETM, ETM2) in all studied foraminiferal taxa. Longterm benthic foraminiferal $\delta^{13} \mathrm{C}$ and $\delta^{18} \mathrm{O}$ results agree with records from other oceans, in particular with the multi-site compilation of [12]. The benthic $\delta^{18} \mathrm{O}$ data show a pronounced $2 \%$ increase during the middle Eocene, which is usually interpreted as a long-term post-EECO cooling.

2. In contrast, no substantial surface water cooling during the middle Eocene is indicated by the $\delta^{18} \mathrm{O}$ of planktic foraminiferal calcite at Site 401. These new data are consistent with data from Tanzania [59] that suggest only a minimal decrease in surface ocean temperatures from the EECO into the middle Eocene. We propose that either (i) that the North Atlantic (and maybe other low latitudinal regions) might have been less sensitive to the well known southern hemisphere climate cooling during the middle Eocene and/or (ii) that the (proto-)Gulf stream transported continuously warm surface waters into the eastern North Atlantic resulting in rather constant surface water temperatures. Further, we conclude that previously suggested surface ocean cooling in the (sub-)tropical Pacific Ocean based on planktic foraminiferal $\delta^{18} \mathrm{O}$ is most likely a consequence of sea-floor diagenesis. 
Fig. 1:

Global geographic map of the Eocene. Sites shown on the map are of scientific importance for the study interval and are included in the intersite comparison.

3. The early-middle Eocene transition is represented by an hiatus or several hiati resulting in low average sedimentation rates. Following this transition the Atlantic Ocean experienced a major change in the sedimentary regime with an increase in sedimentation rates and the onset of drift deposits. Changes in the $\delta^{18} \mathrm{O}$ gradients accompanied with this event suggest different surface water temperature histories for different ocean basins.

4. In general the benthic $\delta^{13} \mathrm{C}$ records show only very small gradients between the studied ocean basins with a tendency toward somewhat heavier values for the Southern Ocean site. This gradient in combination with the observed benthic-planktic decoupling over the middle Eocene suggests that the dominant deep or intermediate water source was positioned in the Southern Ocean that brought the southern hemisphere cooling signal to the North Atlantic intermediate waters as recorded in the benthic foraminiferal $\delta^{18} \mathrm{O}$ of DSDP Site 401.

\section{Acknowledgments}

This research used samples and data provided by the ODP. The ODP was sponsored by NSF and participating countries under the management of Joint Oceanographic Institutions (JOI). Financial support was provided by the DFG to AB (BO2505/4-1, BO2505/5-1). RPS and SD were funded by the Research Foundation Flanders (FWO- G.0422.10) and the Research Fund KU Leuven tions of RDN. We thank Mark Leckie and one anonymous reviewer for their constructive comments.

\section{Figure captions}


Fig. 2:

Age-depth plot with estimated long-term average sedimentation rates at DSDP Site 401. Th. = Thanetian, Pal. = Paleocene, GTS = Geological time scale, EMET = early-middle Eocene transition, $\mathrm{SR}=$ sedimentation rate.

Fig. 3:

SEM and reflected light-microscope images of planktic and benthic foraminifera tests analyzed in this study.

Fig. 4:

Complete $\delta^{13} \mathrm{C}$ and $\delta^{18} \mathrm{O}$ records against meters below sea-floor (mbsf) generated for DSDP Site 401. EMET = early-middle Eocene transition.

Fig. 5:

Isotope gradients between surface dwelling, subsurface dwelling and benthic foraminifera for DSDP Site 401. In this figure only samples with paired measurements have been considered. EMET = early-middle Eocene tran-

Fig. 6:

Intersite comparison between DSDP Site 401 (Atlantic) and ODP Sites 865, 1209 (both central Pacific) and 690 (Maud Rise, Southern Ocean) with respect to the $\delta^{13} \mathrm{C}(\mathrm{A})$ and $\delta^{18} \mathrm{O}(\mathrm{B})$ composition of the different water masses [bottom waters - epibenthics (Cibicidoides spp., Nuttallides truempyi, the latter taxon has been corrected according to Katz et al., 2003), thermocline waters (Subbotina, Hantkenina), and surface waters (Acarinina, Morozovella, Morozovelloides)]. Age scale according to GTS2012. Temperatures have been tentatively estimated based on different assumptions for bottom, thermocline and surface water $\delta^{18} \mathrm{O}_{s w}$ $[93,76]$. A sea-water $\delta^{18} \mathrm{O}_{s w}$ composition $-0.96 \%$ was assumed for thermocline and deep-waters. For the surface ocean different estimates for $\delta^{18} \mathrm{O}_{s w}$ have been used with respect to the NE Atlantic (red, Site 401, $-0.4 \%$ SMOW), the central Pacific (green, Sites 865 and 1209, $-0.15 \%$ SMOW), eastern equatorial Atlantic (Demerara Rise, Sites 1258/1260, $0.34 \%$ SMOW), and the Southern Ocean and South Atlantic (blue, Sites 690 and 1262, -1.15\% SMOW). Abbreviations: DR - Demerara Rise, Cramer - refers to the benthic foraminiferal isotope compilation data by 
[12], BWT - bottom water temperatures, TWT - thermocline water temperatures, SST - sea-surface temperatures. EMET = early-middle Eocene transition.

Fig. 7:

Surface-water (large squares) and bottom water temperatures (small circles) of selected sites which provide benthic and mixed-layer planktic foraminifera data applying the same assumption as in Figure 6. EMET = earlymiddle Eocene transition, B. = Bartonian, Th. = Thanetian.

\section{References}

[1] Aubry, M.P., 1995. From chronology to stratigraphy: interpreting the Lower and Middle Eocene stratigraphic record in the Atlantic Ocean. SEPM Spec. Publ. 54, 213-274.

[2] Axelrod, D.I., 1984. An Interpretation of Cretaceous and Tertiary biota in polar-regions. Palaeogeogr. Palaeoclimatol. Palaeoecol. 45, 105-147.

[3] Berggren, W.A., Pearson, P.N., 2005. A revised tropical to subtropical Paleogene planktonic foraminiferal zonation. J. Foraminif. Res. 35, 279298.

[4] Bice, K., Norris, R., 2005. Data report: Stable isotope ratios of foraminifers from ODP Leg 207, Sites 1257, 1259, and 1260, and a cleaning procedure for foraminifers in organic-rich shales. Proc. Ocean Drill. Progr. Scientif. Res. 207, Ms 207SR-104.

[5] Bice, K.L., Arthur, M.A., Marincovich, L., 1996. Late Paleocene Arctic Ocean shallow-marine temperatures from mollusc stable isotopes. Paleoceanography 11, 241-249.

[6] Bijl, P.K., Bendle, J.A., Bohaty, S.M., Pross, J., Schouten, S., Tauxe, L., Stickley, C.E., McKay, R.M., Röhl, U., Olney, M., Sluijs, A., Escutia, C., Brinkhuis, H., Expedition, S., 2013. Eocene cooling linked to early flow across the Tasmanian Gateway. PNAS 110, 9645-50.

[7] Bijl, P.K., Schouten, S., Sluijs, A., Reichart, G.J., Zachos, J.C., Brinkhuis, H., 2009. Early Palaeogene temperature evolution of the southwest Pacific Ocean. Nature 461, 776-779. 
[8] de Boer, A.M., Sigman, D.M., Toggweiler, J.R., Russell, J.L., 2007. Effect of global ocean temperature change on deep ocean ventilation. Paleoceanography 22 .

[9] Boersma, A., Shackleton, N., Hall, M., Given, Q., 1979. Carbon and oxygen isotope records at DSDP Site 384 ( North Atlantic) and some Paleocene paleotemperatures and carbon isotope variations in the Atlantic Ocean. Init. Rep. Deep Sea Drill. Proj. 43, 695-718.

[10] Bornemann, A., Norris, R.D., Lyman, J.A., D'haenens, S., Groeneveld, J., Röhl, U., Farley, K.A., Speijer, R.P., 2014. Persistent environmental change after the Paleocene-Eocene Thermal Maximum in the eastern North Atlantic. Earth Planet. Sci. Lett. 394, 70-81.

[11] Bralower, T.J., Zachos, J.C., Thomas, E., Parrow, M., Paull, C.K., Kelly, D.C., Silva, I.P., Sliter, W.V., Lohmann, K.C., 1995. Late Paleocene to Eocene paleoceanography of the equatorial Pacific-Ocean - Stable isotopes recorded at Ocean Drilling Program Site-865, Allison-Guyot. Paleoceanography $10,841-865$.

[12] Cramer, B.S., Toggweiler, J.R., Wright, J.D., Katz, M.E., Miller, K.G., 2009. Ocean overturning since the Late Cretaceous: Inferences from a new benthic foraminiferal isotope compilation. Paleoceanography 24.

[13] Cramer, B.S., Wright, J.D., Kent, D.V., Aubry, M.P., 2003. Orbital climate forcing of $\delta^{13} \mathrm{C}$ excursions in the late Paleocene-early Eocene (chrons C24nC25n). Paleoceanography 18.

[14] Demicco, R.V., Lowenstein, T.K., Hardie, L.A., 2003. Atmospheric $\mathrm{pCO}_{2}$ since $60 \mathrm{Ma}$ from records of seawater $\mathrm{pH}$, calcium, and primary carbonate mineralogy. Geology 31, 793-796.

[15] D’haenens, S., Bornemann, A., Claeys, P., Röhl, U., Steurbaut, E., Speijer, R.P., 2014. A transient deep-sea circulation switch during Eocene Thermal Maximum 2. Paleoceanography 29, 370-388.

[16] D'haenens, S., Bornemann, A., Stassen, P., Speijer, R., 2012. Multiple early

Eocene benthic foraminiferal assemblage and $\delta^{13} \mathrm{C}$ fluctuations at DSDP Site 401 (Bay of Biscay - NE Atlantic). Mar Micropaleontol 88-89, 15-35. 
[17] Dutton, A., Lohmann, K.C., Leckie, R.M., 2005. Insights from the Paleogene tropical Pacific: Foraminiferal stable isotope and elemental results from Site 1209, Shatsky Rise. Paleoceanography 20.

[18] Dutton, A., Lohmann, K.C., Leckie, R.M., 2006. Data report: Stable isotope and $\mathrm{Mg} / \mathrm{Ca}$ of Paleocene and Eocene foraminifers, ODP Site 1209, Shatsky Rise. Proc. Ocean Drill. Progr. Scientif. Res. 198, Ms 198SR-119.

[19] Edgar, K.M., Anagnostou, E., Pearson, P.N., Foster, G.L., 2015. Assessing the impact of diagenesis on $\delta^{11} \mathrm{~B}, \delta^{13} \mathrm{C}, \delta^{18} \mathrm{O}, \mathrm{Sr} / \mathrm{Ca}$ and $\mathrm{B} / \mathrm{Ca}$ values in fossil planktic foraminiferal calcite. Geochim. Cosmochim. Acta 166, 189209.

[20] Edgar, K.M., Pälike, H., Wilson, P.A., 2013. Testing the impact of diagenesis on the $\delta^{18} \mathrm{O}$ and $\delta^{13} \mathrm{C}$ of benthic foraminiferal calcite from a sediment burial depth transect in the equatorial pacific. Paleoceanography 28, 468 480 .

[21] Erez, J., Luz, B., 1983. Experimental paleotemperature equation forplanktonic-foraminifera. Geochim. Cosmochim. Acta 47, 1025-1031.

[22] Expedition 342 Scientists, A., 2012. Paleogene Newfoundland Sediment Drifts - 1 June-30 July 2012. IODP Prelim. Rep. 342, doi:10.2204/iodp.pr.342.2012.

[23] Frakes, L.A., Francis, J.E., Syktus, J.I., 1992. Climate modes of the Phanerozoic; The history of the Earth's climate over the past 600 million Years. Cambridge University Press, Cambridge.

[24] Hohbein, M.W., Sexton, P.F., Cartwright, J.A., 2012. Onset of North Atlantic Deep Water production coincident with inception of the Cenozoic global cooling trend. Geology 40, 255-258.

[25] Hollis, C.J., Taylor, K.W.R., Handley, L., Pancost, R.D., Huber, M., Creech, J.B., Hines, B.R., Crouch, E.M., Morgans, H.E.G., Crampton, J.S., Gibbs, S., Pearson, P.N., Zachos, J.C., 2012. Early Paleogene temperature history of the southwest Pacific Ocean: Reconciling proxies and models. Earth Planet. Sci. Lett. 349-350, 53-66.

[26] Huber, M., Sloan, L., Shellito, C., 2003. Early Paleogene oceans and climate: A fully coupled modeling approach using the NCAR CCSM. Geol. Soc. Am. Spec. Pap. 369, 25-47. 
[27] Huber, M., Sloan, L.C., 2000. Climatic responses to tropical sea surface temperature changes on a "greenhouseëarth. Paleoceanography 15, 443450.

[28] Inglis, G.N., Farnsworth, A., Lunt, D., Foster, G.L., Hollis, C.J., Pagani, M., Jardine, P.E., Pearson, P.N., Markwick, P., Galsworthy, A.M.J., Raynham, L., Taylor, K.W.R., Pancost, R.D., 2015. Descent toward the Icehouse: Eocene sea surface cooling inferred from GDGT distributions. Paleoceanography 30, 1000-1020.

[29] Katz, M.E., Katz, D.R., Wright, J.D., Miller, K.G., Pak, D.K., Shackleton, N.J., Thomas, E., 2003. Early Cenozoic benthic foraminiferal isotopes: Species reliability and interspecies correction factors. Paleoceanography 18.

[30] Kennett, J.P., Stott, L.D., 1990. Proteus and proto-oceanus: ancestral Paleogene oceans as revealed from Antarctic stable isotopic results; ODP Leg 113. Proc. Ocean Drill. Progr. Scientif. Res. 113, 865-880.

665 [31] Kennett, J.P., Stott, L.D., 1991. Abrupt deep-sea warming, palaeoceanographic changes and benthic extinctions at the end of the Paleocene. Nature $353,225-229$.

[32] Kirtland Turner, S., Sexton, P.F., Charles, C.D., Norris, R.D., 2014. Persistence of carbon release events through the peak of early Eocene global warmth. Nature Geosci. 7, 748-751.

[33] Komar, N., Zeebe, R.E., Dickens, G.R., 2013. Understanding long-term carbon cycle trends: The late Paleocene through the early Eocene. Paleoceanography $28,650-662$.

[34] Kozdon, R., Kelly, D.C., Kita, N.T., Fournelle, J.H., Valley, J.W., 2011. Planktonic foraminiferal oxygen isotope analysis by ion microprobe technique suggests warm tropical sea surface temperatures during the Early Paleogene. Paleoceanography 26.

[35] Kroopnick, P.M., 1985. The distribution of $13 \mathrm{C}$ of SCO2 in the world oceans. Deep-Sea Res. Part A 32, 57-84.

${ }_{680}$ [36] Lagabrielle, Y., Goddéris, Y., Donnadieu, Y., Malavieille, J., Suarez, M., 2009. The tectonic history of Drake Passage and its possible impacts on global climate. Earth Planet. Sci. Lett. 279, 197-211. 
[37] Lawver, L.A., Gahagan, L.M., 2003. Evolution of Cenozoic seaways in the circum-Antarctic region. Palaeogeogr. Palaeoclimatol. Palaeoecol. 198, 1137 .

[38] Lear, C.H., Elderfield, H., Wilson, P.A., 2000. Cenozoic deep-sea temperatures and global ice volumes from $\mathrm{Mg} / \mathrm{Ca}$ in benthic foraminiferal calcite. Science 287, 269-272.

[39] Littler, K., Röhl, U., Westerhold, T., Zachos, J.C., 2014. A high-resolution benthic stable-isotope record for the South Atlantic: Implications for orbital-scale changes in Late Paleocene-Early Eocene climate and carbon cycling. Earth and Planetary Science Letters 401, 18-30.

[40] Lourens, L.J., Sluijs, A., Kroon, D., Zachos, J.C., Thomas, E., Röhl, U., Bowles, J., Raffi, I., 2005. Astronomical pacing of late Palaeocene to early Eocene global warming events. Nature 435, 1083-1087.

[41] Martini, E., 1970. Standard Palaeogene calcareous nannoplankton zonation. Nature 226, 560-561.

[42] McGowran, B., 1989. Silica burp in the eocene ocean. Geology 17, 857-860.

[43] McInerney, F.A., Wing, S.L., 2011. The Paleocene-Eocene Thermal Maximum: A perturbation of carbon cycle, climate, and biosphere with implications for the future. Annu. Rev. Earth Planet. Sci. 39, 489-516.

[44] Miller, K.G., Curry, W.B., 1982. Eocene to Oligocene benthic foraminiferal isotopic record in the Bay of Biscay. Nature 296, 347-350.

[45] Miller, K.G., Fairbanks, R.G., Mountain, G.S., 1987. Tertiary oxygen isotope synthesis, sea level history, and continental margin erosion. Paleoceanography 2, 1-19.

[46] Miller, K.G., Wright, J.D., Browning, J.V., 2005. Visions of ice sheets in a greenhouse world. Marine Geol. 217, 215-231.

[47] Montadert, L., Roberts, D., Auffret, G., Bock, W., Dupeuble, P., Hailwood, E., Harrison, W., Kagami, H., Lumsden, D., Müller, C., et al., 1979. Site 401. Init. Rep. Deep Sea Drill. Proj 48, 73-124.

[48] Müller, C., 1979. Calcareous nannofossils from the North Atlantic (Leg 48). Init. Rep. Deep Sea Drill. Proj 48, 589-639. 
[49] Müller, G., Gastner, M., 1971. The "Karbonat-Bombe", a simple device for the determination of the carbonate content in sediments, soils, and other materials. N. Jb. Min. 10, 466-469.

[50] Muttoni, G., Kent, D.V., 2007. Widespread formation of cherts during the early Eocene climate optimum. Palaeogeogr. Palaeoclimatol. Palaeoecol. $253,348-362$.

[51] Norris, R., 1996. Symbiosis as an evolutionary innovation in the radiation of Paleocene planktic foraminifera. Paleobiology 22, 461-480.

[52] Norris, R.D., Kirtland Turner, S., Hull, P.M., Ridgwell, A., 2013. Marine ecosystem responses to Cenozoic global change. Science 341, 492-498.

[53] Norris, R.D., Klaus, A., Kroon, D., 2001a. Mid-Eocene deep water, the late Palaeocene thermal maximum and continental slope mass wasting during the Cretaceous-Palaeogene impact. Geol. Soc. Spec. Publ. 183, 23-48.

[54] Norris, R.D., Kroon, D., Huber, B.T., Erbacher, J., 2001b. CretaceousPalaeogene ocean and climate change in the subtropical North Atlantic. Geol. Soc. Spec. Publ. 183, 1-22.

[55] Okada, H., Bukry, D., 1980. Supplementary modification and introduction of code numbers to the low-latitude coccolith biostratigraphic zonation (Bukry, 1973, 1975). Mar. Micropaleontol. 5, 321-325.

[56] Pagani, M., Zachos, J.C., Freeman, K.H., Tipple, B., Bohaty, S., 2005. Marked decline in atmospheric carbon dioxide concentrations during the Paleogene. Science 309, 600-603.

[57] Pearson, P., Wade, B., 2007. Stable warm tropical climate through the eocene epoch: Reply. Geology 35, e153.

[58] Pearson, P.N., Ditchfield, P.W., Singano, J., Harcourt-Brown, K.G., Nicholas, C.J., Olsson, R.K., Shackleton, N.J., Hall, M.A., 2001. Warm tropical sea surface temperatures in the Late Cretaceous and Eocene epochs. Nature 413, 481-487.

[59] Pearson, P.N., van Dongen, B.E., Nicholas, C.J., Pancost, R.D., Schouten, S., Singano, J.M., Wade, B.S., 2007. Stable warm tropical climate through the Eocene Epoch. Geology 35, 211-214. 
[60] Pearson, P.N., Olsson, R.K., Huber, B.T., Hemleben, C., Berggren, W.A.. (Eds.), 2006. Atlas of Eocene planktonic foraminifera. volume 41. Cushman Foundation Special Publication.

[61] Pearson, P.N., Palmer, M.R., 2000. Atmospheric carbon dioxide concentrations over the past 60 million years. Nature 406, 695-699.

750 [62] Pearson, P.N., Shackleton, N.J., Hall, M.A., 1993. Stable isotope paleoecology of Middle Eocene planktonic foraminifera and multi-species isotope stratigraphy, DSDP Site 523, South Atlantic. J. Foraminif. Res. 23, 123146 .

[63] Pospichal, J.J., Wise, S.W., 1990. Paleocene to Middle Eocene calcareous nannofossils of ODP Sites 689 and 690, Maud Rise, Weddell Sea. Proc. Ocean Drill. Progr. Scientif. Res. 113, 613-638.

[64] Premoli Silva, I., Wade, B., Pearson, P., 2006. Taxonomy of Globigerinatheka and Orbulinoides, in: Pearson, P., Olsson, R., Huber, B., Hemleben, C., Berggren, W. (Eds.), Atlas of Eocene Planktonic Foraminifera. Cushman Foundation. volume 41 of Cushman Foundation Special Publication, pp. 169-212.

[65] Sarmiento, J.L., Hughes, T.M., Stouffer, R.J., Manabe, S., 1998. Simulated response of the ocean carbon cycle to anthropogenic climate warming. Nature 393, 245-249.

[66] Sexton, P.F., Norris, R.D., Wilson, P.A., Pälike, H., Westerhold, T., Röhl, U., Bolton, C.T., Gibbs, S., 2011. Eocene global warming events driven by ventilation of oceanic dissolved organic carbon. Nature 471, 349-353.

[67] Sexton, P.F., Wilson, P.A., Norris, R.D., 2006a. Testing the Cenozoic multisite composite $\delta^{18} \mathrm{O}$ and $\delta^{13} \mathrm{C}$ curves: New monospecific Eocene records from a single locality, Demerara Rise (Ocean Drilling Program Leg 207). Paleoceanography 21.

[68] Sexton, P.F., Wilson, P.A., Pearson, P.N., 2006b. Palaeoecology of late middle Eocene planktic foraminifera and evolutionary implications. Mar. Micropaleontol. 60, 1-16.

775 [69] Shackleton, N., 1974. Attainment of isotopic equilibrium between ocean water and the benthonic foraminifera genus Uvigerina - isotopic changes in 
the ocean during the last glacial, in: Labeyrie, L. (Ed.), Colloquium CNRS, pp. 203-209.

[70] Sluijs, A., Brinkhuis, H., Schouten, S., Bohaty, S.M., John, C.M., Zachos,

[75] Thomas, D.J., Bralower, T.J., Jones, Charles E., L., 2003. Neodymium isotopic reconstruction of late Paleocene-early Eocene thermohaline circulation. Earth Planet. Sci. Lett. 209, 309-322.

[76] Tindall, J., Flecker, R., Valdes, P., Schmidt, D.N., Markwick, P., Harris, J., 2010. Modelling the oxygen isotope distribution of ancient seawater using a coupled ocean-atmosphere GCM: Implications for reconstructing early Eocene climate. Earth Planet. Sci. Lett. 292, 265-273.

[77] Tripati, A., Elderfield, H., 2005. Deep-sea temperature and circulation changes at the Paleocene-Eocene thermal maximum. Science 308, 1894-

[78] Tripati, A.K., Delaney, M.L., Zachos, J.C., Anderson, L.D., Kelly, D.C., Elderfield, H., 2003. Tropical sea-surface temperature reconstruction for the early Paleogene using $\mathrm{Mg} / \mathrm{Ca}$ ratios of planktonic foraminifera. Paleoceanography 18, 1-13. 
[79] Tripati, A.K., Eagle, R.A., Morton, A., Dowdeswell, J.A., Atkinson, K.L., Bahe, Y., Dawber, C.F., Khadun, E., Shaw, R.M.H., Shorttle, O., Thanabalasundaram, L., 2008. Evidence for glaciation in the Northern Hemisphere back to $44 \mathrm{Ma}$ from ice-rafted debris in the Greenland Sea. Earth Planet. Sci. Lett. 265, 112-122.

[80] Tucholke, B., Mountain, G., 1986. Tertiary paleoceanography of the western North Atlantic Ocean, in: Vogt, P., Tucholke, B. (Eds.), The Geology of North America. Geological Society of America Boulder, Colo. volume M of Geological Society of Amerika Special Publication, pp. 631-650.

[81] Vandenberghe, N., Hilgen, F., Speijer, R., 2012. The Paleogene period, in: Gradstein, F., Ogg, J., Schmitz, M., Ogg, G. (Eds.), A Geologic Time Scale 2012. Elsevier. volume 2, pp. 855-921.

[82] Voigt, J., Hathorne, E.C., Frank, M., Holbourn, A., 2016. Minimal influence of recrystallization on middle miocene benthic foraminiferal stable isotope stratigraphy in the eastern equatorial pacific. Paleoceanography 31, 98-114.

${ }_{825}$ [83] Wachter, E.A., Hayes, J.M., 1985. Exchange of oxygen isotopes in carbon dioxide-phosphoric acid systems. Chem. Geol. 52, 365-374.

[84] Wade, B.S., Pearson, P.N., Berggren, W.A., Pälike, H., 2011. Review and revision of Cenozoic tropical planktonic foraminiferal biostratigraphy and calibration to the geomagnetic polarity and astronomical time scale. EarthSci. Rev. 104, 111-142.

[85] Westerhold, T., Röhl, U., Donner, B., McCarren, H.K., Zachos, J.C., 2011. A complete high-resolution Paleocene benthic stable isotope record for the central Pacific (ODP Site 1209). Paleoceanography 26.

[86] Westerhold, T., Röhl, U., Laskar, J., Raffi, I., Bowles, J., Lourens, L.J., Zachos, J.C., 2007. On the duration of magnetochrons C24r and C25n and the timing of early Eocene global warming events: Implications from the Ocean Drilling Program Leg 208 Walvis Ridge depth transect. Paleoceanography 22 .

[87] Westerhold, T., Röhl, U., Raffi, I., Fornaciari, E., Monechi, S., Reale, V., Bowles, J., Evans, H.F., 2008. Astronomical calibration of the Paleocene time. Palaeogeogr. Palaeoclimatol. Palaeoecol. 257, 377-403. 
[88] Wolfe, J.A., 1980. Tertiary climates and floristic relationships at highlatitudes in the northern hemisphere. Palaeogeogr. Palaeoclimatol. Palaeoecol. 30, 313-323.

[89] Zachos, J., Pagani, M., Sloan, L., Thomas, E., Billups, K., 2001. Trends, rhythms, and aberrations in global climate 65 Ma to present. Science 292, 686-693.

[90] Zachos, J., Wara, M., Bohaty, S., Delaney, M., Petrizzo, M., Brill, A., Bralower, T., Premoli-Silva, I., 2003. A transient rise in tropical sea surface temperature during the Paleocene-Eocene Thermal Maximum. Science 302, $1551-1554$.

[91] Zachos, J.C., Dickens, G.R., Zeebe, R.E., 2008. An early Cenozoic perspective on greenhouse warming and carbon-cycle dynamics. Nature 451, 279-283.

[92] Zachos, J.C., McCarren, H., Murphy, B., Röhl, U., Westerhold, T., 2010. Tempo and scale of late Paleocene and early Eocene carbon isotope cycles: Implications for the origin of hyperthermals. Earth Planet. Sci. Lett. 299, $242-249$.

[93] Zachos, J.C., Stott, L.D., Lohmann, K.C., 1994. Evolution of early Cenozoic marine temperatures. Paleoceanography 9, 353-387. 


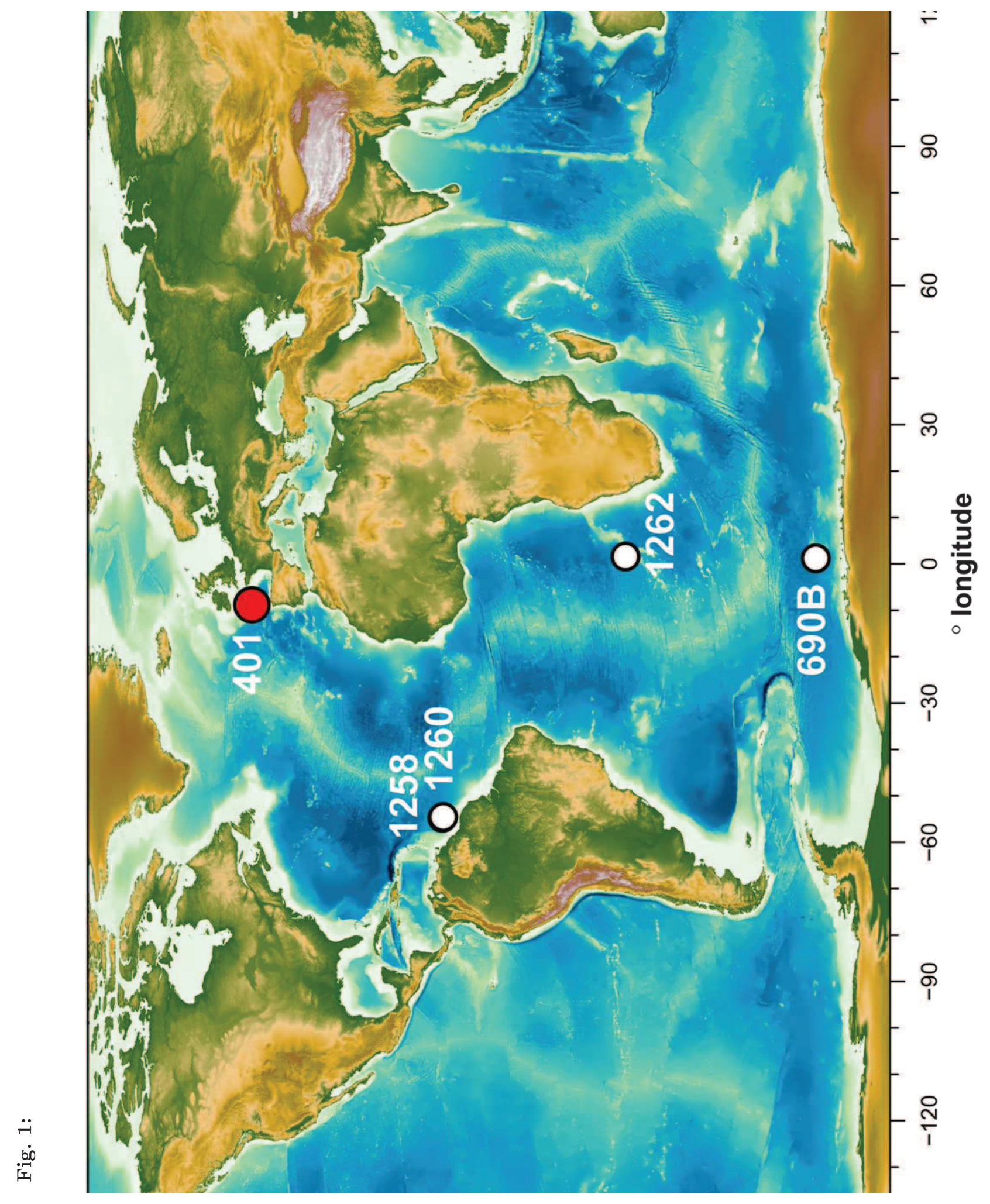




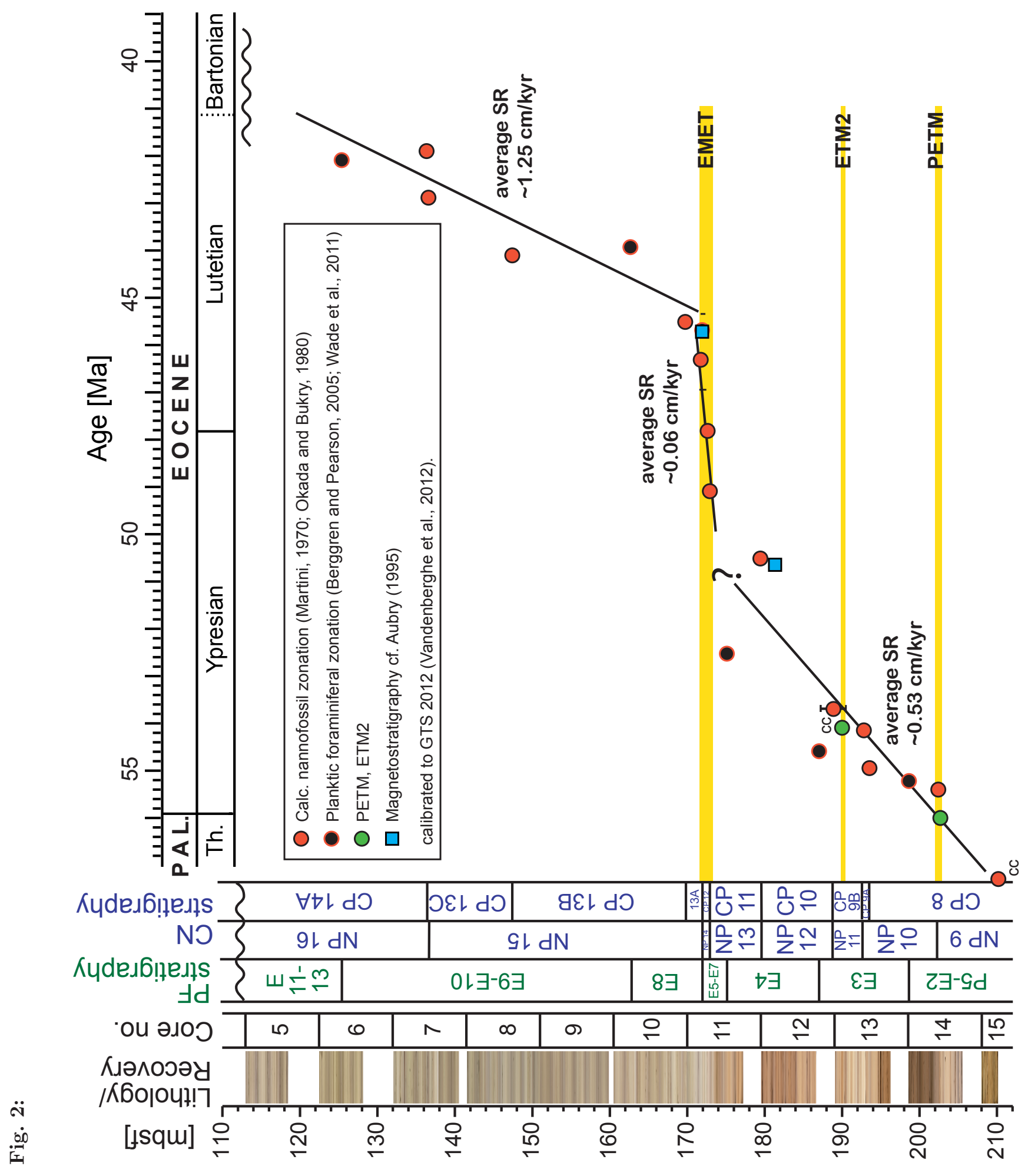




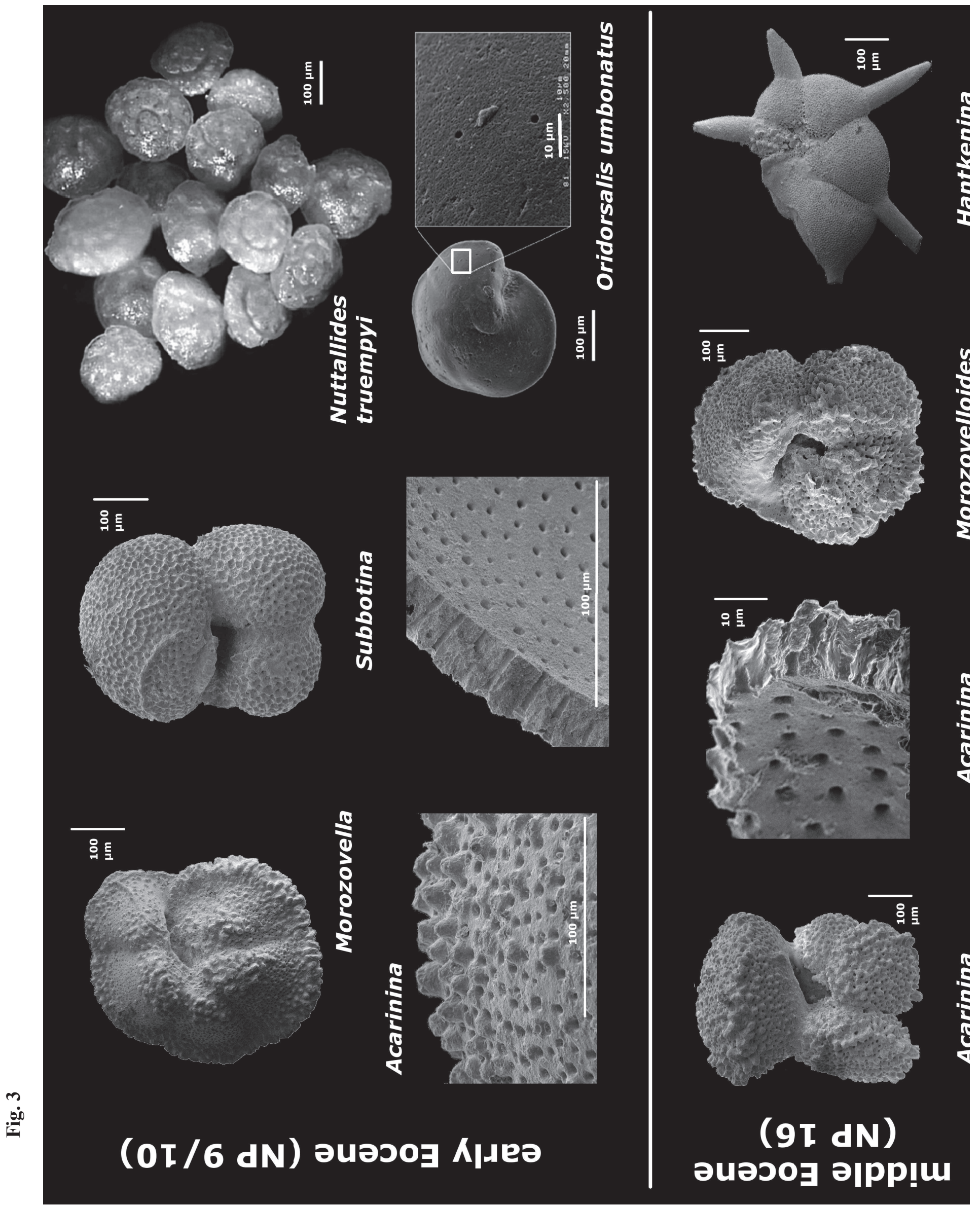



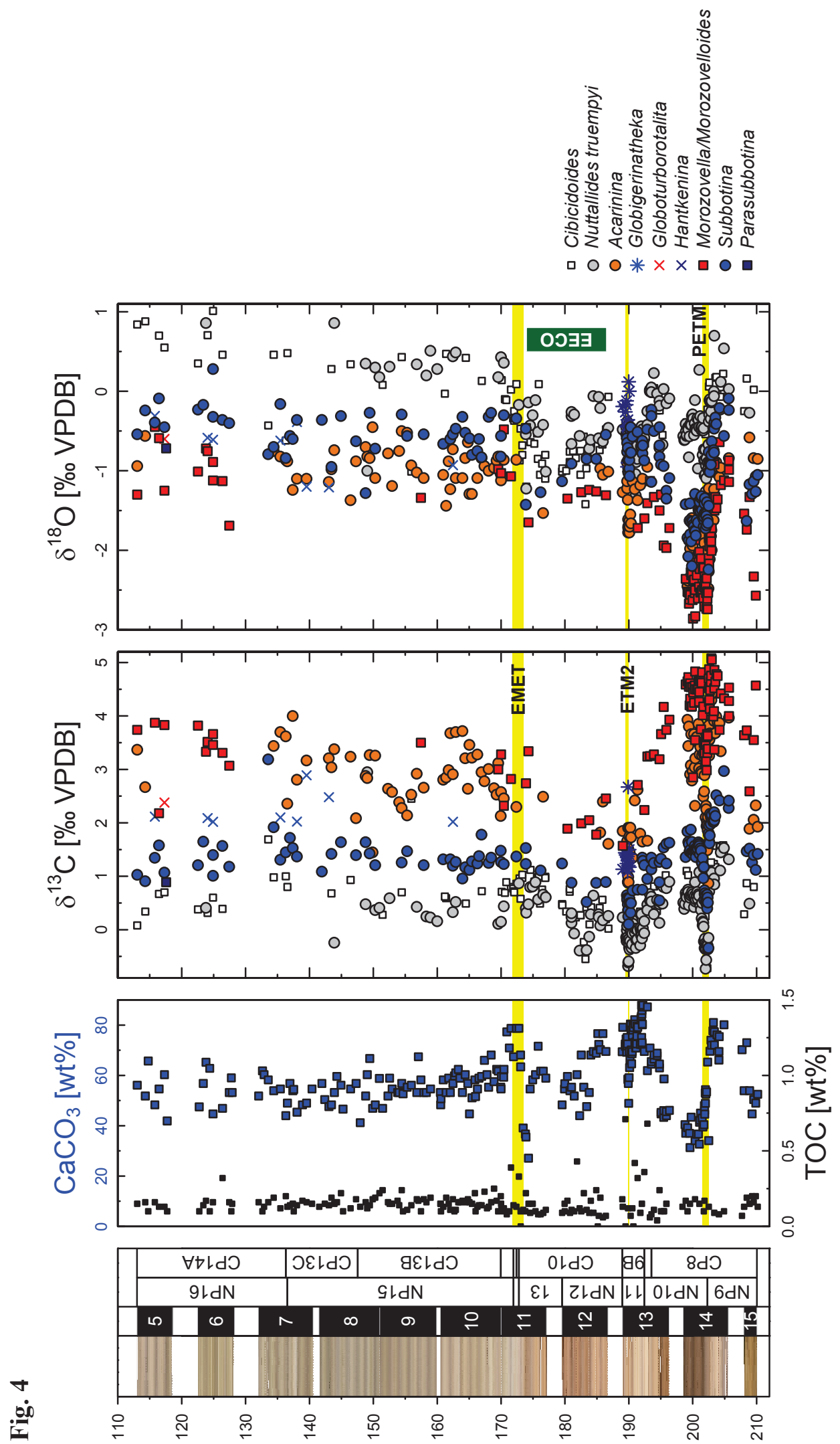


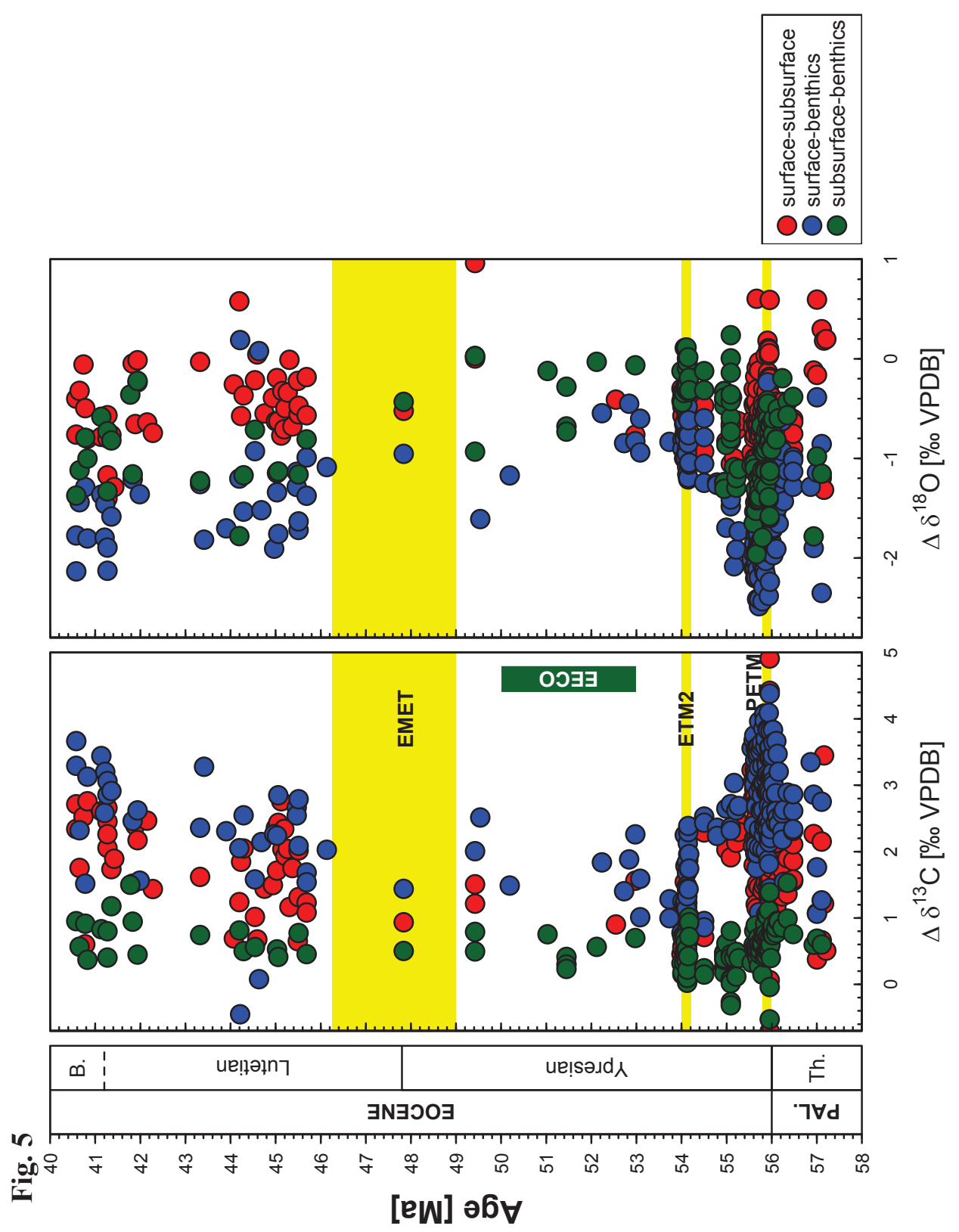


Fig. 6

$\delta^{13} \mathrm{C}$ [\% VPDB]

benthics

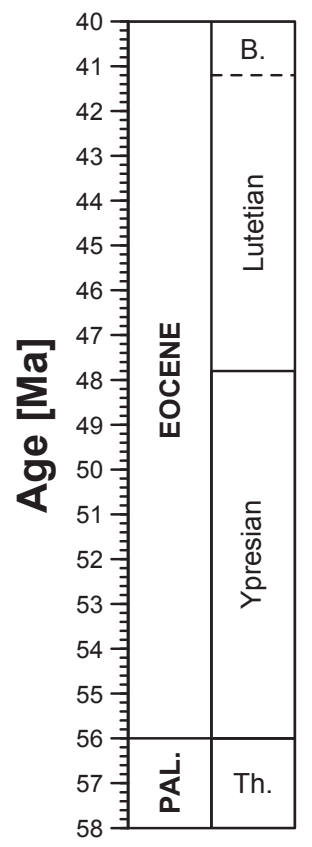

thermocline

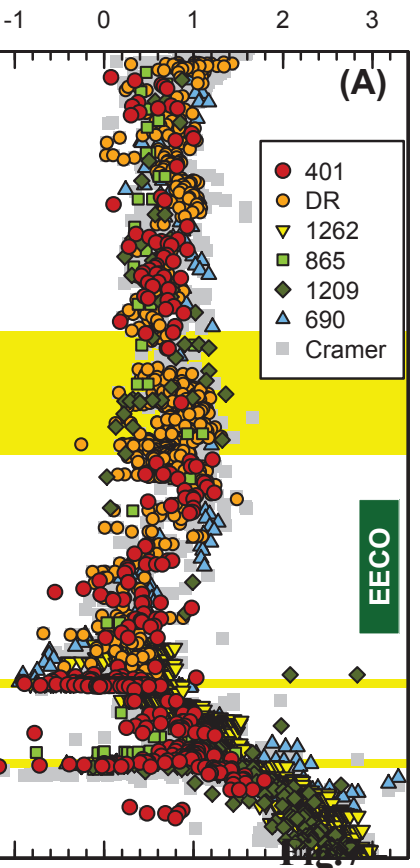

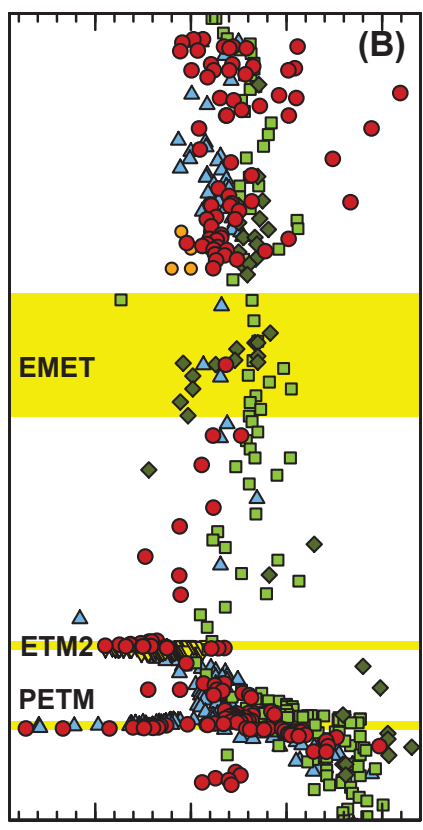

surface

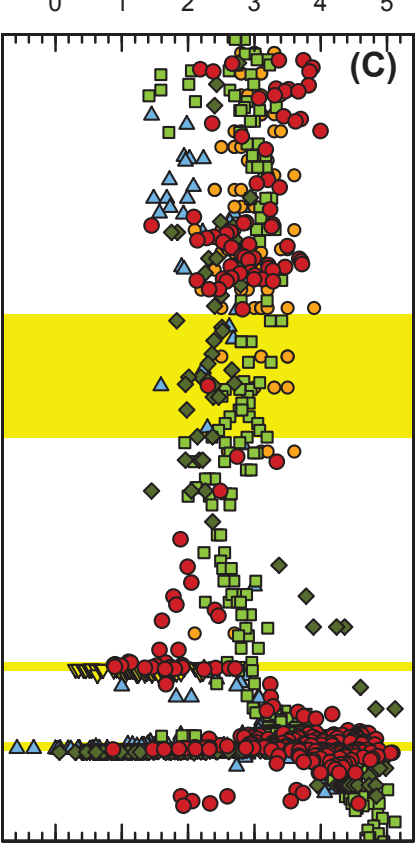

$\delta^{18} \mathrm{O}[\%$ VPDB]
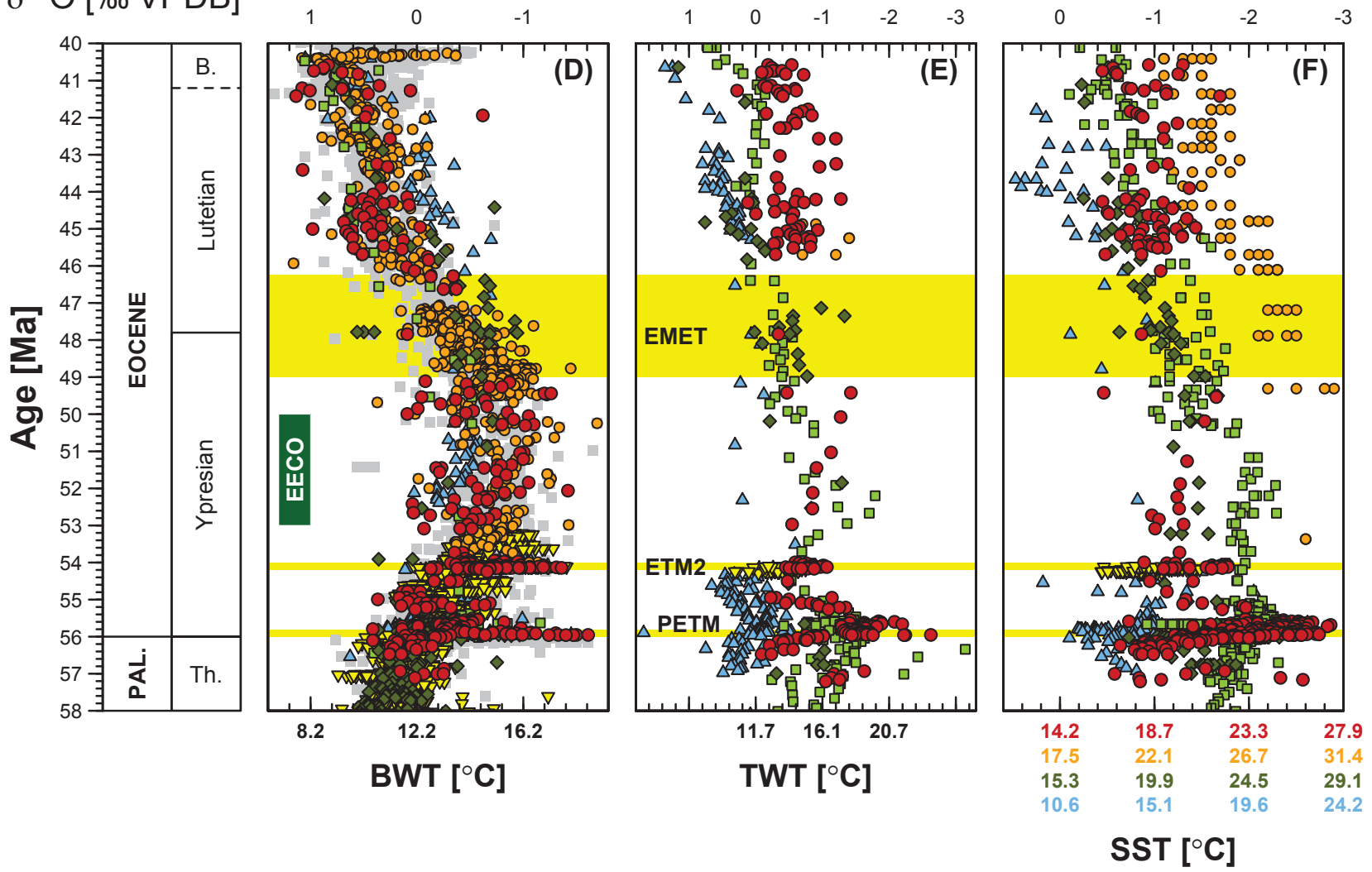


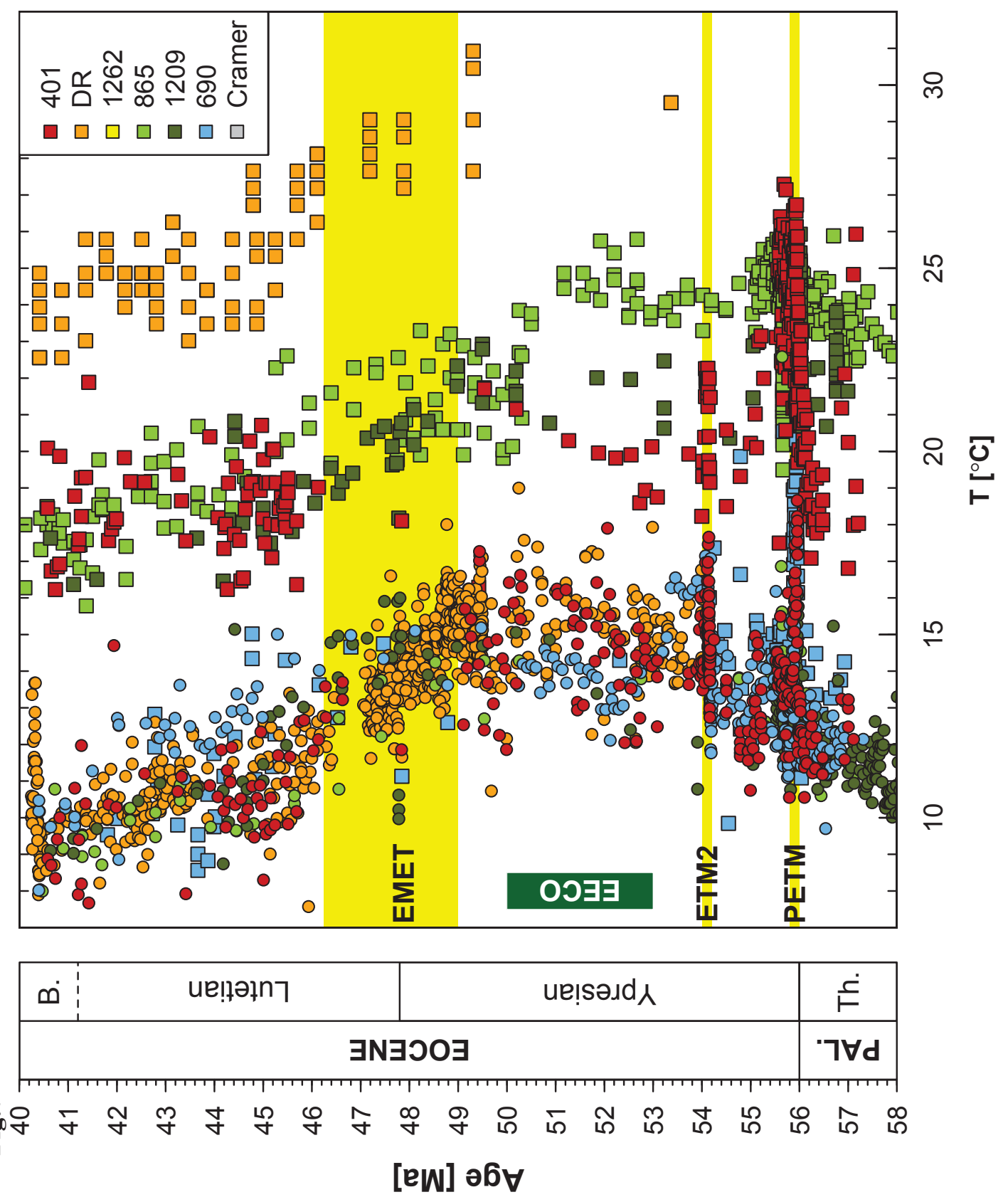

